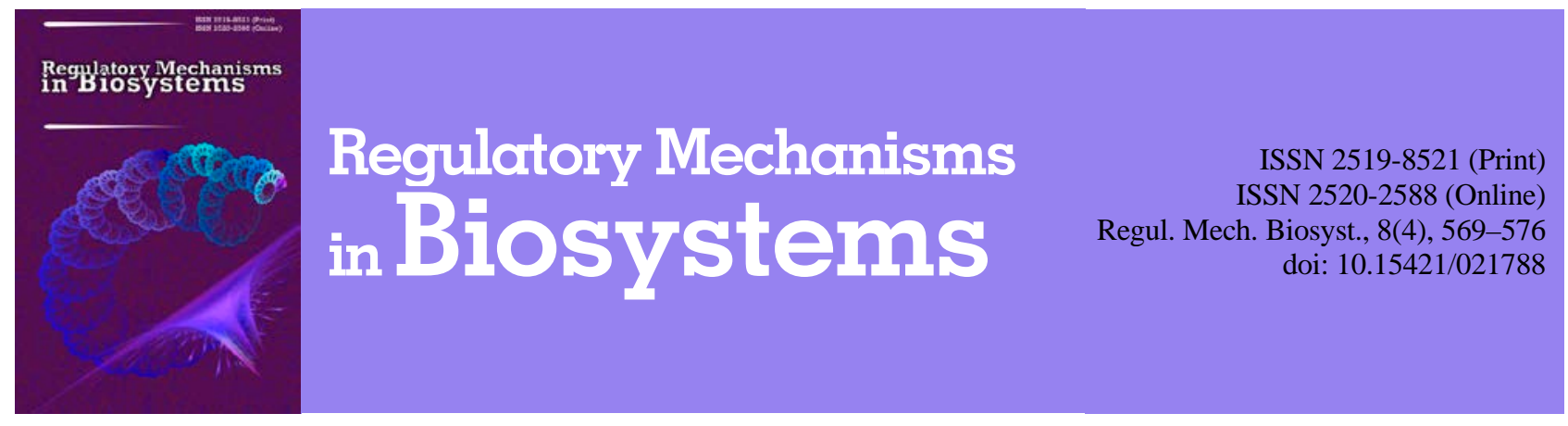

\title{
Hysto-ultrastructure of the facial nerve and mimic muscles in the norm and in the conditions of experimental neuropathy
}

\author{
V. Myhailiuk*, I. Mykhailiuk*, M. Hembarovskyi*, O. Lebid*, K. Duda*, L. Patskan*, N. Shovkova** \\ *I. Horbachevsky Ternopil State Medical University, Ternopil, Ukraine \\ **Ivano-Frankivsk National Medical University, Ivano-Frankivsk, Ukraine
}

Article info

Received 30.09.2017

Received in revised form 08.11.2017

Accepted 10.11.2017

I. Horbachevsky Ternopil State Medical University,

Chekhov st., 3

Ternopil, 46003, Ukraine.

Ivano-Frankivsk National Medical University,

Galitcka st., 2,

Ivano-Frankivsk, 76000, Ukraine.

Tel. +38-067-415-60-87

E-mail: luch1959@ukr.net
Myhailiuk, V., Mykhailiuk, I., Hembarovskyi, M., Lebid, O., Duda, K., Patskan, L., \& Shovkova, N. (2017). Hystoultrastructure of the facial nerve and mimic muscles in the norm and in the conditions of experimental neuropathy. Regulatory Mechanisms in Biosystems, 8(4), 569-576. doi:10.15421/021788

We studied the structural components of the facial nerve in the norm and with cold neuropathy, indicating morphological changes in neuromuscular endings and muscle fibers at 10, 15, 30 and 60 days from the beginning of the simulation of experimental neuropathy, which was caused by local supercooling of the projection portions of the extracranial parts of the facial nerve on the background of the preliminary introduction of Freud's complete adjuvant. We established that the pathomorphological changes in the endonevral microcirculatory bed have a phase character: the initial spasm (up to 10 days) changes in paralytic vasodilation, and its residual effects remain until the end of the experiment (60 days). Changes in hemomicrocirculation conditions lead to marked disturbances in the structure of myelinic nerve fibers, which have the character of segmental demyelination with signs of delay in axonal transport and reactive restructuring of neuromuscular endings. The change in the metric composition of myelinated nerve fibers is due to an increase in the number of nerve fibers of medium and large diameters (up to 30 days) and small diameter (after 30 days). In different periods of the experiment, a decrease in the branching area of the terminal branches of the motor axon is observed in the nerve cells, local edema of the endonevria, degenerative changes in a part of the nerve fibers develop. Due to the fine-grained decay of the final nerve branches, degeneration of the motor endings took place two weeks after the start of the experiment. Neuropathy for 30 days caused a pronounced inhibition of spotting in the peripheral parts of the motor nerve fibers. After 60 days of experiment, a large number of muscle fibers underwent destructive changes. The size of a significant part of the neuromuscular endings was reduced. In all terms of cold neuropathy, neurolematocytes reacted in the same way: cytoplasm was swollen, argyrophilic grains appeared in the nuclei, fine-grained decay of individual nuclei occurred.

Keywords: facial nerve; mimic muscles; nerve fibers; nerve-muscle endings; muscular fibers; cold neuropathy; microcirculatory network

\section{Гісто-ультраструктура лицевого нерва та мімічних м'язів у нормі та в умовах експериментальної нейропатії}

\author{
В. М. Михайлюк*, І. А. Михайлюк*, М. В. Гембаровський*, \\ О. І. Лебідь*, К. М. Дуда*, Л. О. Пацкань*, Н. І. Шовкова**
}

*Тернопільський держсавний медичний університет імені I. Я. Горбачевського МОЗ Украӥни, Тернопіль, Украӥна

**Івано-Франківський національний медичний університет, Івано-Франківськ, Украйна

\footnotetext{
Проведено дослідження структурних компонентів лицевого нерва в нормі та за холодової нейропатії, що вказує на морфологічні зміни в нервово-м'язових закінченнях і м'язових волокнах через 10, 15, 30 і 60 діб від початку моделювання експериментальної нейропатії, яку викликали локальним переохолодженням ділянки проекції позачерепної частини лицевого нерва на фоні попереднього введення повного ад’юванта Фрейда. Патоморфологічні зміни ендоневрального мікроциркуляторного русла мають фазовий характер: початковий спазм (до 10-ї доби) змінюється паралітичною вазодилятацією, а ії залишкові явища зберігаються до кінця експерименту (60-та доба). Зміни умов гемомікроциркуляції викликають виражені порушення структури мієлінових нервових волокон, які мають характер сегментарної демієлінізації з ознаками затримання аксонного транспорту та реактивної перебудови нервово-м'язових закінчень. Зміна метричного складу мієлінових нервових волокон, відбувається внаслідок збільшення кількості нервових волокон середнього та великого діаметрів (до 30-ї доби) та дрібного діаметра (після 30-ї доби). У різні терміни експерименту в нервових елементах спостерігається зменшення площі розгалуження термінальних гілок рухового аксона, локальний набряк ендоневрію, розвиваються дегенеративні зміни частини нервових волокон. Унаслідок дрібнозернистого розпаду кінцевих нервових гілочок через два тижні після початку експерименту відбувається
} 
дегенерація моторних закінчень. Нейропатія протягом 30 діб викликає виражене гальмування спраутингу у периферичних відділах рухових нервових волокон. Через 60 діб експерименту велика кількість м’язових волокон піддається деструктивним змінам. Розміри значної частини нервово-м'язових закінчень зменшуються. В усі терміни холодової нейропатії нейролемоцити реагують однотипно: спостерігається набряк цитоплазми, в ядрах з'являються аргірофільні зерна, відбувається дрібнозернистий розпад окремих ядер.

Ключові слова: лицевий нерв; нервові волокна; нервово-м’язові закінчення; м’язові волокна; холодова нейропатія; мікроциркуляторне русло

\section{Вступ}

Труднощі в лікуванні нейропатій черепних і периферичних нервів вимагають від морфологів комплексного вивчення їх компонентів (нервових волокон, мікросудин і сполучнотканинних елементів) як у нормі, так і за патологіï (Gitik et al., 2011; Ali et al., 2015; Hamel and Logigian, 2017). При цьому вивчення гісто-ультраструктури лицевого нерва посідає одне 3 провідних місць у нейроморфології (Reina et al., 2015), оскільки його нейропатії складають 2-3\% всіх захворювань периферичної нервової системи (Mumtaz and Jensen, 2014) і зустрічаються найчастіше серед уражень черепних нервів (Fayad and Linthicum, 2014; Azizzadeh et al., 2014).

Для сучасної медицини значний теоретичний і практичний інтерес становлять також дані про перебудову структури периферійного нервово-м'язового апарату за нейропатій різного генезу (Popel', 2017), а також під час переходу процесу у хронічне рецидивування, яке зустрічається у $40 \%$ пацієнтів із нейропатією лицевого нерва (Fayad and Linthicum, 2014; Watanabe and Suzuki, 2016). Розкриття причин цих процесів створює передумови для дослідження способів їх лікування та корекції з метою підтримання на достатньому рівні функціонального стану нервових і м'язових волокон і запобігання можливим рецидивам (Boissaud-Cooke et al., 2015; Lemaster et al., 2017).

У літературі існує протиріччя щодо характеру патологічних змін у мієлінових нервових волокнах за холодової нейропатії (Nawaz et al., 2013; Mumtaz and Jensen, 2014; Cohen et al., 2015). Одні дослідники відносять ці зміни до первинних, визнаючи при цьому виражений характер деструкції, швидкоплинність і зворотність процесів (Achiron and Miron, 2007). Інші вважають їх вторинними, які розвиваються внаслідок по-рушення місцевого кровообігу (Zheng et al., 2012; Tuhrim, 2016). Треті притримуються теорії порушення нейрогуморальної регуляції місцевого метаболізму мієлінових нервових волокон (Nanba et al., 2010). Донині не встановлено наявності у структурі лицевого нерва безмієлінових нервових волокон, а стосовно їх реакції на локальний вплив холоду взагалі не проведено досліджень. У літературі відсутні також дані про перебудову рухових нервових закінчень мімічних м'язів за нейропатії лицевого нерва (Popel', 2017), тоді як у світлі сучасних запитів практичної нейростоматології вивчення механізмів адаптивних змін у компонентах лицевого нерва та його термінальних нервовом'язових закінченнях за впливу місцевого охолодження становлять значний інтерес (Smith et al., 2012).

Мета статті - виявити особливості нейро-вазо-десмальних взаємовідношень у лицевому нерві в нормі та за експериментальної холодової нейропатії.

\section{Матеріал і методи досліджень}

Будова нервових провідників та нервово-м'язових закінчень лицевого нерва вивчена поряд з особливостями мікроциркуляторного русла в нормі (5 кролів) та за холодової нейропатії (30 кролів), яку моделювали за запропонованою методикою на кафедрі анатомії людини Івано-Франківського національного медичного університету (рац. пропозиція № 32/2049 MO3 України від 05.11.91р.). Для дослідження нервових і м’язових волокон використовували такі методи: 1) тонкої ін'єкції судин хлороформно-ефірною сумішшю паризької синьої 3 наступним просвітленням препаратів і метилметакрилатом для приготування корозійних препаратів та вивчення у сканувальному електронному мікроскопі JEOL-25A-T3225 (Японія); 2) імпрегнації судин в епіневрії за Купріяновим; 3) виявлення нервових волокон за Кульчицьким, Масон і Ренсон із наступним обчис- ленням індексу $g$ (співвідношення діаметра аксона до діаметра цілого мієлінового нервового волокна); 4) виявлення продуктів розпаду мієліну за Маркі; 5) одночасного виявлення на поперечному перерізі нервового стовбура нервових волокон і кровоносних судин із застосуванням морфометрії; 6) імпрегнації рухових нервових закінчень у мімічних м'язах за Більшовським - Грос; 7) трансмісивної електронної мікроскопії за допомогою електронного мікроскопа ПЕМ-100К (Selmi, Україна) та 8) морфометричного, кореляційного та інформаційного аналізу.

Тварин виводили з експерименту на 10, 15, 30, 45 і 60-ту добу згідно 3 «Правилами гуманного поводження 3 експериментальними тваринами» та «Загальними етичними принципами експериментів на тваринах».

Паралельно 3 лицевим нервом вивчали м'язи верхньої та нижньої губи, які піддавали гістологічному дослідженню. Після фіксації шматочків мімічних м'язів у $12 \%$ нейтральному формаліні та поміщення в парафінові блоки їх зрізи фарбували гематоксиліном та еозином, пікрофуксином, імпрегнували азотнокислим сріблом за Більшовським і Більшовським - Гросс.

Діаметр нервових волокон, розміри нервово-м'язових закінчень і капілярів визначали за допомогою комп’ютерної програми Biovision 4.01. Отримані дані обробляли методами непараметричної статистики 3 використанням показника Манна Уїтні. Комп'ютерне опрацювання даних проводили за допомогою статистичного пакета Statistica 6 (StatSoft Inc., Tulsa, USA). Використовували непараметричні методи дослідження (критерій Уїлкоксона, Манна - Уїтні). Вибіркові параметри, наведені далі в таблицях і тексті, мають такі позначення: $\mathrm{x}$ - вибіркове середне, SE - стандартна помилка середнього. Статистичні зміни вважали достовірними тоді, коли отриманий рівень вірогідності для тестової статистики був меншим прийнятого рівня достовірності $(\mathrm{P}<0,05)$.

\section{Результати}

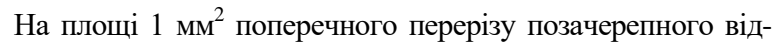
ділу лицевого нерва нараховано $9187 \pm 593$ (91,3\%) мієлінових нервових волокон та $615 \pm 23(8,7 \%)$ безмієлінових нервових волокон, а певні коливання їх кількості визначаються неоднаковою щільністю розташування в ендоневрії. При цьому кількість мієлінових нервових волокон різних груп варіює: дрібних (1,0-4,0 мкм) - 580-998 (13-21\%), середніх (4,1-7,0 мкм) 2987-3859 (22-32\%) і великих (понад 7,0 мкм) - 4022-6110 (52-61\%). Великих волокон завжди більше, ніж середніх та дрібних, що визначає унімодальний розподіл мієлінових нервових волокон на гістограмах. При цьому діаметр осьового циліндра дрібних волокон коливається від 0,4 до 1,2 мкм, середніх - від 1,3 до 2,9 мкм і великих - від 4,1 до 8,6 мкм, а показник g становить відповідно 0,28, 0,43 і 0,50. Такі незначні його коливання в усіх розмірних групах мієлінових нервових волокон вказують на прямопропорційну залежність між діаметром аксона та товщиною мієлінової оболонки.

Кровоносне русло лицевого нерва складається із двох взаємозв'язаних судинних сіток: епі- та ендоневральної, які мають різну просторову архітектоніку. Магістральні епіневральні судини - джерело артеріол, які проникають у товщу нервового стовбура, поступово розгалужуються та утворюють п’ятикомпонентне ендоневральне гемомікроциркуляторне русло. При цьому внутрішньостовбурові капіляри діаметром 2-10 мкм формують петлі ромбоподібної або полігональної форми, розмір яких варіює у широких межах: від 320,0-540,0 в довжину до 40,0-

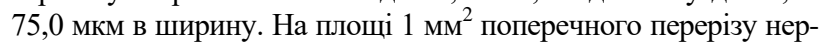
ва нараховується $140,0 \pm 9,4$ капілярів, сумарна ємність яких 
складає 18664 мкм $^{3}$. Капіляри діаметром 1,0-4,0 мкм (12,6\%), $4,1-7,0$ мкм $(56,4 \%)$ і більше 7,0 мкм $(31,0 \%)$ розміщуються у сполучнотканинних прошарках між нервовими волокнами різного діаметра на відстані 42,0-86,0 мкм один від одного. Кожний капіляр забезпечує живлення певної групи нервових волокон разом 3 їх сполучнотканинним оточенням у радіусі 47,5-67,1 мкм. «Зони васкуляризації» капілярів становлять 6230,0 мкм $^{2}$ і перекривають одна одну, за рахунок чого створюються надійні умови кровопостачання цих груп нервових волокон, особливо тих, які розташовані на віддалі від основного джерела живлення.

На площі васкуляризації кожного гемокапіляра міститься в середньому 68-89 мієлінових і 4-12 безмієлінових нервових волокон. Між кількістю нервових волокон і капілярів існує тісний позитивний кореляційний взаємозв'язок $(\mathrm{r}=0,83)$, який вказує на зростання кількості капілярів за збільшення кількості мієлінових нервових волокон і навпаки.

На 10-ту добу після локального охолодження ділянки проекції лицевого нерва у позачерепній частині окремі мієлінові нервові волокна дрібного та середнього діаметра зазнають периаксональних змін: спостерігається нерівномірність їх фарбування ванслідок набряку та часткового руйнування мієлінової оболонки (рис. 1). Підтвердження цього - їх метричний перерозподіл (зменшення кількості дрібних нервових волокон і збільшення кількості середніх і великих) та зменшення показника g. У претермінальних ділянках рухових аксонів утворю- ються локальні звуження та варикозні розширення, зменшується площа їх термінальних розгалужень (рис. 2). Під час електронномікроскопічного дослідження виявляється зменшення ширини та довжини активних зон пресинаптичної мембрани, довжини синаптичних контактів, кількості постсинаптичних складок і синаптичних пухирців. Переважна більшість безмієлінових нервових волокон у складі лицевого нерва при цьому залишається інтактною.

У кровоносному руслі у цей термін спостерігається звуження просвіту артеріальних і розширення венозних судин, збільшення кількості функціонуючих артеріоло-венозних анастомозів. Через це зменшується кількість внутрішньостовбурових капілярів та їх сумарна ємкість відповідно на 46,7\% (P < $0,001)$ та $24,3 \%$ ( $<0,001)$, тоді як площа «зон васкуляризації» одним внутрішньостовбуровим капіляром збільшується в середньому на $24,7 \%(\mathrm{P}<0,001)$. Це зумовлює збільшення кількості нервових волокон (в 1,4 раза), які припадають на один капіляр; у 2,6 раза збільшується кількість мієлінових нервових волокон, розташованих у цих «зонах».

На 15-ту добу експерименту структурні зміни в ділянці охолодження лицевого нерва поглиблюються. У більшості мієлінових нервових волокон спостерігається виражений набряк мієлінової оболонки, порушення ії дрібнокоміркової структури та забарвлення, локальна вакуолізація та деструкція - причина варикозних розширень і оголення аксонів (рис. 3), що підтверджується також електронномікроскопічно.

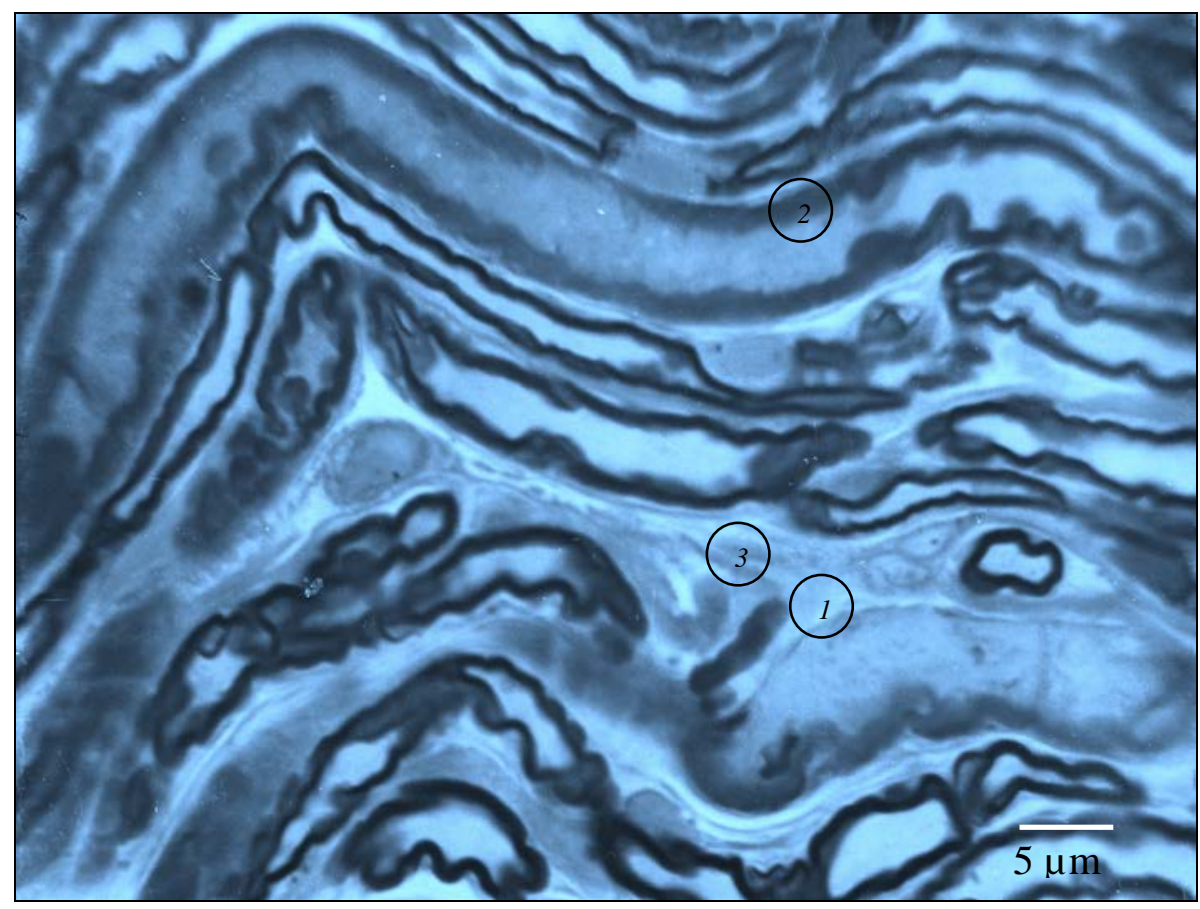

Рис. 1. Патоморфологічні зміни нервових волокон на 10-ту добу експериментальної нейропатії: спостерігаються сегментарна демієлінізація (1), розволокнення та варикозні розширення мієлінової оболонки (2), локальний набряк ендоневрія (3); забарвлення за Кульчицьким

Виявляється помітний набряк і нерівномірна імпрегнація осьових циліндрів не тільки в мієлінових, а й у безмієлінових нервових волокнах. У набряклому ендоневрії методом Маркі виявляються продукти деградації мієліну (ельцгольцівські тільця). Такі зміни гістоструктури нервових волокон більше виражені у пучках, які розміщуються поверхнево. Порівняно з попереднім терміном дослідження ці явища спричиняють ще більше «перекалібрування» метричного розподілу мієлінових нервових волокон: зменшується кількість дрібних і середніх, збільшується - великих мієлінових нервових волокон, за зменшення показника g. Наслідок деміслінізації окремих осьових циліндрів - зменшення загальної кількості мієлінових нервових волокон на площі $1 \mathrm{mм}^{2}$ поперечного перерізу нерва (на препаратах, забарвлених за Кульчицьким), тоді як число безмієлінових нервових волокон не змінюється. У претермінальних і термінальних відділах рухових аксонів лицевого нерва також відбувається поглиблення дезінтеграційних процесів. Спостерігаються варикозні розширення та фрагментація окремих претерміналей, на 42,6\% зменшується периметр терміналей, тоді як довжина синаптичної щілини зменшується на $73,3 \%$, при цьому руйнуються окремі нервово-м'язові закінчення. Під час електронномікроскопічного дослідження виявляється розширення синаптичної щілини та «вклинювання» цитоплазматичних відростків кінцевих нейролемоцитів, зменшується кількість синаптичних пухирців в аксоплазмі терміналей, частково фрагментується пресинаптична мембрана, а також частково дезінтегруються окремі складки постсинаптичної мембрани. 
У цей термін відбувається згущення гемомікроциркуляторної сітки нерва за рахунок розвитку постхолодової паралітичної вазодилятації. При цьому капілярні петлі зменшуються в розмірах до 65-160 x 45-60 мкм, тоді як кількість внутрішньостовбурових гемокапілярів на площі $1 \mathrm{mм}^{2}$ поперечного перерізу лицевого нерва збільшується до $156,0 \pm$ 5,3 (P < 0,05). Діаметр просвіту складових частин мікроциркуляторного русла збільшується на 4-20 мкм. У зв'язку з цим відбувається певний метричний перерозподіл внутрішньостовбурових капілярів: значно зменшується кількість дрібних та збільшується - мікросудин середнього та великого діаметра.

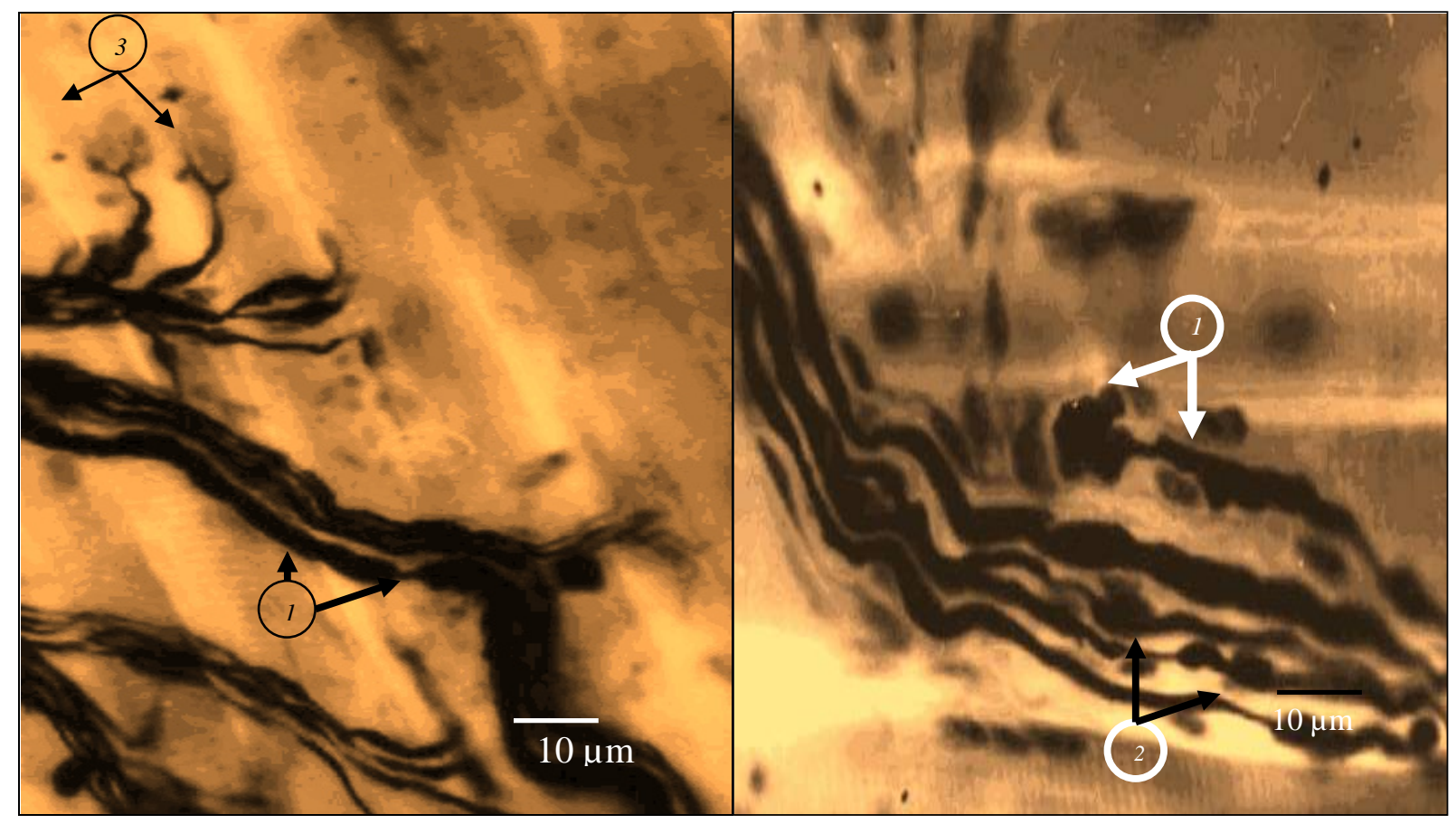

Рис. 2. Патоморфологічні зміни у претермінальних ділянках аксонів на 10-ту (a) та 15-ту (б) добу експерименту: варикозні розширення (1), локальні звуження (2), зменшення довжини та площі розгалуження термінальних гілок рухових аксонів (3); імпрегнація за Більшовським - Гросс

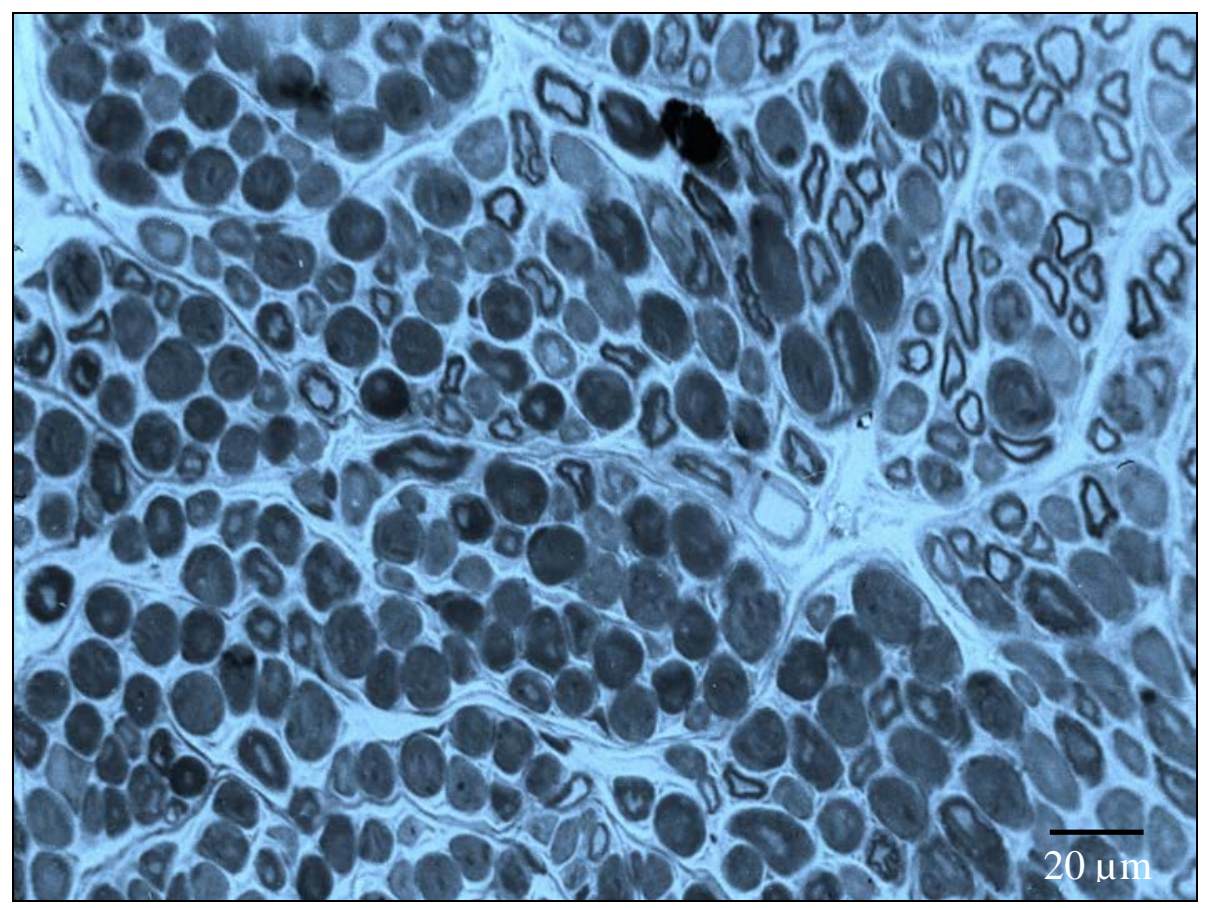

Рис. 3. Патоморфологічні зміни нервових волокон на 15-ту добу експериментальної нейропатії: виражений набряк, розволокнення та дисхромія мієлінової оболонки; забарвлення: за Кульчицьким

Через 30 діб після початку моделювання холодової нейропатії характерне поєднання деструктивних і початкових репаративних процесів у мієлінових нервових волокнах лицевого нерва: мієлінова оболонка більшості з них має різне забарвлення за рахунок чергування ділянок гіпер- і гіпохромної інтенсивності, ламели мієліну розволокнені, виявляються широкі ділянки сегментарної демієлінізації нервових волокон із накопиченням у цитоплазмі нейролемоцитів та ендоневральних макрофагів продуктів розпаду мієліну. Під час електронномікроскопічного дослідження виявляються ділянки оголеної аксолеми, тоді як аксоплазма має підвищену електронну щільність. $\mathrm{y}$ цитоплазмі нейролемоцитів спостерігаються фагосоми та 
зруйнований мієлін у вигляді $\pi$-гранул. Поряд із цим спостерігаються аксони мієлінових нервових волокон, оточені поодинокими шарами мієліну, які свідчать про початок ремієлінізувальних процесів. У цитоплазмі нейролемоцитів, які оточують такі нервові волокна, виявляється збільшена кількість мітохондрій 3 електроннощільним матриксом і упорядкованими кристами, чітко структурована гранулярна ендоплазматична сітка 3 великою кількістю прикріплених до її поверхні цистерн рибосом. Більшість безмієлінових нервових волокон, як і в попередні терміни, залишаються інтактними. Під час кількісного та морфометричного аналізу мієлінових нервових волокон виявляється зменшення їх загальної кількості та збільшення серед них числа великих за діаметром волокон, тоді як дрібні та середні волокна ще більше зменшуються порівняно 3 нормою, а їх кількість зростає порівняно з попереднім терміном $(\mathrm{P}<0,05)$. Показник $\mathrm{g}$ для дрібних волокон збільшується, однак порівняно 3 попереднім терміном практично не змінюється для середніх і великих нервових волокон.

У цей термін у претермінальних і термінальних ділянках аксонів відбуваються незначні зрушення: вони майже не відрізняються від структури, яка виявлялася у попередньому терміні досліджень. При цьому аксони мають локальні потоншення, ділянки гіперімпрегнації, варикозні розширення та часткову фрагментацію. Однак зменшується кількість синаптичних пухирців у ділянках активних зон, довжина синаптичних щілин і периметр синаптичних контактів у термінальних відділах аксонів. Синаптичні пухирці концентруються, як правило, поряд із пресинаптичною мембраною, субсинаптична зона містить кристалоподібні включення, тоді як у центральній частині терміналі спостерігається значна кількість нейрофіламентів у стані агрегації. Поряд із цим у мітохондріях пре- та субсинаптичних зон проявляються різні за напрямком адаптаційні зміни: окремі 3 них мають електроннощільний матрикс і добре контуровані кристи, інші - 3 просвітленим матриксом і дезінтегрованими кристами. В ядрах окремих нейролемоцитів відбувається каріопікноз.

Основна риса мікроциркуляторного русла лицевого нерва через 30 діб після початку моделювання експериментальної нейропатії - зменшення діаметра просвіту всіх мікросудин, внаслідок чого розріджується ангіоархітектоніка. При цьому відбувається «перекалібрування» внутрішньостовбурових капілярів: збільшується кількість мікросудин середнього калібру і розмір петель гемокапілярної сітки (до 110-230 × 55-80 мкм) та зменшується сумарна ємкість капілярного русла (до 10295 мм³). Середній радіус «зони васкуляризації» кожного капіляра становить 42,3 мкм, що на 14,5\% менше, ніж до початку експерименту.

На 45-ту добу після локальної холодової травми лицевого нерва відбувається активація відновних процесів: у більшості мієлінових нервових волокон відсутній набряк мієлінової оболонки, вони рівномірно забарвлюються, мають рівні контури, упорядковуються ламели, насічки та вузли (нодуси) мієліну, в ендоневральних макрофагах і цитоплазмі нейролемоцитів виявляється менша кількість продуктів розпаду мієліну, збільшується число ремієлінізованих аксонів, аксоплазма яких містить активовані мітохондрії та упорядковані мікротрубочки. Загаль-

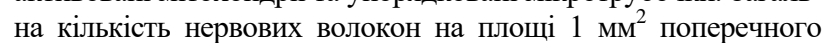
перерізу нерва підвищується порівняно 3 попереднім терміном, але все ще залишається нижчою за норму. Відбуваються зміни у метричному складі мієлінових нервових волокон: підвищується кількість дрібних нервових волокон і, навпаки, зменшується кількість великих нервових волокон. Підтвердження цьому - збільшення показника g, особливо у групі дрібних і середніх волокон. Переважна більшість безмієлінових нервових волокон залишається інтактною.

Претермінальні та термінальні ділянки рухових аксонів лицевого нерва у цей термін характеризуються поєднанням деструктивних і репаративних явищ, коли поряд із частково або повністю деструктуризованими нервово-м'язовими закінчен- нями виявляються заново сформовані закінчення 3 тонкою структурою їх елементів. На ультраструктурному рівні такі нервово-м'язові закінчення мають відновлені елементи пресинаптичної мембрани, поглиблені складки постсинаптичної мембрани, рівномірне розташування синаптичних пухирців у кінцевих відділах аксоплазми, впорядковані мікротрубочки, сформовані активні синаптичні зони. Для них характерні численні нові функціонально активні аксоплазматичні та саркоплазматичні мітохондрії, відновлення структури кінцевих нейролемоцитів.

Кровоносне русло лицевого нерва у цей термін ще більше розріджується, зменшується, наближається до норми діаметр просвіту мікросудин, особливо артеріальної частини. Через це продовжує збільшуватись кількість дрібних і середніх внутрішньостовбурових капілярів, тоді як число великих зменшується. Збільшуються відстань між сусідніми капілярами та площа їх «зон васкуляризації», розміри капілярних петель також збільшуються. Все це зумовлює зменшення сумарної ємності кровоносного русла нерва, кількості нервових волокон, які розташовані в кожній «зоні васкуляризації» і які припадають на один капіляр $(\mathrm{P}<0,05)$.

Через 60 діб із початку моделювання експериментальної нейропатії лицевого нерва його мієло- та ангіоархітектоніка наближаються до таких у нормі. При цьому загальна кількість мієлінових нервових волокон (хоча і не вірогідно - $\mathrm{P}>0,05$ ) все ж залишається меншою. Менше порівняно з нормою нараховується нервових волокон великого діаметра, тоді як кількість дрібних із тонкою мієліновою оболонкою - більша. Це підтверджує продовження процесів ремієлінізації. Показник g збільшується в усіх розмірних групах нервових волокон. Нейролемоцити таких нервових волокон містять дещо більших розмірів ядро $з$ дисперсно розподіленим хроматином, упорядковані цистерни гранулярної ендоплазматичної сітки та складові частини пластинчастого апарату Гольджі, функціонально активні мітохондрії, велику кількість рибосом і полісом. В аксоплазмі виявляються збільшена кількість мітохондрій, чітко упорядковані мікротрубочки та нейрофіламенти. Спостерігаються поодинокі мієлінові нервові волокна з розволокненою, войлокоподібною, частково зруйнованою або фрагментованою мієліновою оболонкою, 3 вираженими «натіканнями» аксоплазми - ознака затримування аксотоку. На ультраструктурному рівні це проявляється дисоціацією ламел мієліну, його гомогенізацією та розпадом. Продукти розпаду накопичуються у фаголізосомах нейролемоцитів і ендоневральних макрофагах. Помітні вакуолізація цитоплазми нейролемоцитів, патологічні зміни їх органел, підвищення осміофільності аксоплазми, виражена дезорієнтація мікротрубочок.

Як і у попередній термін, у товщі мімічних м'язів поряд із деструктивно зміненими пре- та термінальними відділами рухових аксонів лицевого нерва виявляються новоутворені закінчення, кількість яких порівняно $з$ попереднім терміном збільшується. Зростає також площа таких нервово-м'язових закінчень, але вона менша на 25-30\% за нормальні величини цих структур. На електронномікроскопічному рівні композиція таких новоутворених нервово-м'язових закінчень не відрізняється від норми, але все ще менша довжина пресинаптичної мембрани, кількість і глибина складок постсинаптичної мембрани, число синаптичних пухирців, ще не повністю сформовані активні зони синапсів.

У кровоносному руслі лицевого нерва у цей термін зберігається тенденція до зменшення просвіту його складових частин. При цьому діаметр просвіту судин артеріальної частини не вірогідно відрізняється від норми, тоді як його венозна частина залишається ще розширеною. Морфометрично встановлено зменшення кількості великих та збільшення дрібних і середніх внутрішньостовбурових капілярів, збільшення середнього радіуса та площі зони кровопостачання кожного 3 них, зменшення сумарної ємкості кровоносного русла. При цьому кількість нервових волокон, які припадають на один гемокапіляр, та їх 
число, яке розміщується в кожній із «зон васкуляризації», наближається до норми. Між кількісним і якісним складом нервових волокон і капілярів відновлюється тісний кореляційний зв'язок ( $\mathrm{r}=0,75-0,82)$, що свідчить про наближення основних характеристик мієло- та ангіоархітектоніки до вихідних показників.

Отже, в ранні терміни після локальної холодової травми (10-30-та доба) у структурних компонентах (нервовопровідниковому та судинному) лицевого нерва та нервово-м’язових закінченнях у мімічних м'язах переважають набрякові та дистрофічно-деструктивні процеси, а у віддалені терміни (45-60-та доба) у цих структурах превалюють регенераційно-відновні явища. У м'язових волокнах також відбуваються патоморфологічні зміни, які підтверджуються кількісними показниками.

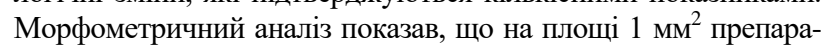
тів мімічних м'язів збільшується загальна кількість капілярів середнього ( $\mathrm{d}=4-7$ мкм) та великого ( $\mathrm{d}>7$ мкм) діаметрів: відповідно на $45,1 \%$ i $52,3 \%$ ( $\mathrm{P}<0,05)$. За рахунок розкриття резервних капілярів стає густішим внутрішньом'язове кровоносне русло. У відповідь на це підвищується площа поперечного перерізу сполучнотканинних прошарків, збільшується кількість гістіоцитів і тканинних базофілів.

Одночасно зменшується площа розгалужень термінальних гілок рухового аксона, які утворюють пресинаптичний полюс нервово-м’язових закінчень (табл.).

\section{Таблиця}

Зміна площі розгалуження термінальних гілок

рухового аксона в різні терміни від початку

моделювання нейропатії лицевого нерва $(\mathrm{x} \pm \mathrm{SE})$

\begin{tabular}{lllll}
\hline \multirow{2}{*}{$\begin{array}{c}\text { Тривалість } \\
\text { експерименту, діб }\end{array}$} & \multicolumn{2}{c}{ Площа розгалужень, мкм ${ }^{2}$} & \multirow{2}{*}{ Р } & \multirow{2}{*}{$\%$} \\
\cline { 2 - 3 } 10 & $239,6 \pm 3,8$ & $206,3 \pm 10,2^{*}$ & $<0,001$ & 14,1 \\
15 & $366,1 \pm 1,8$ & $297,1 \pm 11,3^{*}$ & $<0,01$ & 18,8 \\
30 & $573,7 \pm 36,3$ & $198,2 \pm 21,5^{* *}$ & $<0,01$ & 65,4 \\
60 & $386,5 \pm 10,2$ & $156,7 \pm 18,6^{*}$ & $<0,01$ & 59,4 \\
\hline
\end{tabular}

Примітки: $*$ - $\mathrm{P}<0,05, * *-\mathrm{P}<0.01$ вірогідність показників порівняно 3 попереднім етапом експерименту; $\mathrm{P}$ - відмінності між експериментом і контролем.

\section{Обговорення}

Комплексний аналіз будови нервових волокон і васкуляризації лицевого нерва кроля в нормі та під час холодової нейронпатії дав можливість виявити назку загальних, морфометрично обгрунтованих, структурних i морфофункціональних рис, які мають теоретико-практичне значення. Співставляючи дані наших досліджень і відомості літератури, слід зауважити, що кількість нервових волокон на різних рівнях лицевого нерва пов'язана, перш за все, з ускладненням його плексусної будови, онто- та філогенетично зумовлена (Cohen et al., 2015; Craig and Stone, 2015). Ми встановили, що в лицевому нерві кроля число мієлінових нервових волокон коливається; це спостерігали також інші дослідники, які вивчали мієлоархітектоніку лицевого нерва та інших периферичних нервів тварин і людини (Azizzadeh et al., 2014; Fayad and Linthicum, 2014; Reina et al., 2015).

Обчисливши показник g (співвідношення діаметра аксона до товщини цілого мієлінового волокна) в усіх групах нервових волокон, ми відзначили їх зменшення відповідно до зростання діаметра волокна (0,52-0,56 для дрібних і 0,38-0,48 для великих нервових волокон). Це свідчить про прямо пропорційний зв’язок між діаметром аксона та товщиною мієлінової оболонки, на що вказують також інші автори (Popel', 2017).

Для розкриття патоморфологічних механізмів формування пошкоджень на тканинному та клітинному рівні значний інтерес являє вивчення адаптаційних реакцій організму за допомогою інформаційного аналізу (Craig and Stone, 2015). Тільки окремі автори присвятили свої дослідження вивченню інформаційних показників нервових волокон під час пошкодження периферичних нервів (Popel', 2017). Провівши інформаційний аналіз метричного розподілу нервових волокон і внутрішньостовбурових капілярів на матеріалі власного дослідження, ми встановили, що дві інформаційні підсистеми (нервоволоконна та гемокапілярна) перебувають у тісному позитивному кореляційному взаємозв'язку та взаємозалежності $(\mathrm{r}=0,86)$, що свідчить про взаємозумовленість мієло- та ангіоархітектоніки лицевого нерва.

Це проявляється закономірними змінами кровоносного русла вже на ранніх термінах експерименту, коли спостерігається звуження просвіту артеріальних і розширення венозних судин, збільшення кількості функціональних артеріо-венозних анастомозів. Як і інші автори (Tuhrim, 2016; Hamel and Logigian, 2017), ми стверджуємо, що спазм артерій викликає зменшення кількості внутрішньостовбурових капілярів, що стає причиною зменшення сумарної ємності кровоносного русла.

Зміни, які відбуваються в основних компонентах нервового стовбура за дії локального охолодження, мають фазовий характер, що підтверджує відомості, отримані Feuerstein (2008).

У першій фазі (до 10 діб) відбувається спазм усіх ланок МЦР як епі-, так і ендоневрія, який змінюється у подальшому різким розширенням переважно капілярів і венулярного відділу МЦР. Враховуючи думку Plotnikov et al. (2016), механізм цих змін можна пояснити таким чином: холод, діючи на рецепторні закінчення шкіри, викликає біль, який, у свою чергу, спричинює спазм судин. Власне спазм судин зумовлює виникнення ішемії, що викликає спазм і біль. Таким чином, коло замикається, а постійна аферентна імпульсація досягає підкоркової ділянки, яка, відповідаючи виділенням надлишку адреналіноподібних речовин, викликає негайний спазм судин, тим самим підтримуючи ішемічний стан тканин. Гостре охолодження спричиняє також мобілізацію ендогенних катехоламінів (Keith, 2007). У другій фазі відбуваються порушення окисновідновних процесів, дистрофічні зміни тканин і параліч вазомоторного апарату, що проявляється різким розширенням просвіту судин, втратою тонусу їх стінки. Патофізіологічними дослідженнями доведено, що за ішемії та гіпоксії судинна стінка стає дуже податливою (Abramowitz and Gertz, 2007; BoissaudCooke et al., 2015; Lemaster et al., 2017). Третя фаза стійкіша, зумовлена повільними темпами відновних процесів. Popel' (2017) показав, що на такому фоні площа «зон васкуляризації» одним внутрішньостовбуровим капіляром, навпаки, збільшується, що, за нашими даними, викликає збільшення в 1,4 раза кількості нервових волокон, які припадають на один капіляр, i в 2,6 раза - волокон, розташованих у цих «зонах васкуляризації». На думку Zheng et al. (2012), збільшення чисельності функціонуючих артеріо-венозних анастомозів зумовлене дією вазоактивних речовин (неспецифічні метаболіти, гістамін, серотонін, кінини), що у великій кількості утворюються під час холодової травми (Keith, 2007).

За даними Wagner et al. (2008) i Tracz et al. (2015), підвищене скидання артеріальної крові у вени через артеріо-венулярні анастомози спричиняє зменшення артеріо-венозного градієнта концентрації кисню, порушення окисно-відновних процесів i розвиток ацидозу в навколишніх тканинах, до якого чутливіші мієлінові порівняно з безмієліновими нервовими волокнами.

Таким чином, найбільше виражений компонент реакції на холод - судинна реакція зі змінами стану гістогематичного бар'єру. Як вказують Abramowitz and Gertz (2007), через зменшення тонусу судинної стінки судини мікроциркуляторного русла переповнюються кров’ю, що зумовлює виникнення венозно-капілярного стазу. Це може відбуватися під час зміни реологічних властивостей крові за рахунок підвищення в’язкості крові та зниження дисперсності еритроцитарного потоку за підвищеної фільтрації фракції дрібномолекулярних білків. Порушення проникності судинної стінки, як відомо з праць Aman et al. (2016) i Popel' (2017), - найперший і один із ранніх проявів патології периферичних нервів. У зв’язку зі збільшенням кількості внутрішьостовбурових капілярів відстань між 
ними та радіус їх кровопостачання зменшуються, що викликає звуження «зон васкуляризації» кожного з них і зменшення числа нервових волокон у їх межах. Такі перетворення, на нашу думку, через підвищений стаз крові погіршують трофіку нервових волокон.

Зміни в ангіоархітектоніці нерва, пов’язані зі зменшенням на 14,5\% середнього радіуса «зони васкуляризації» кожного капіляра, викликають зменшення кількості нервових волокон, які припадають на один капіляр і розташовуються в зоні їх васкуляризації. Тривала венозна гіперемія та стаз зумовлені, на думку багатьох авторів (Achiron and Miron, 2007; Gitik et al., 2011; Zheng et al., 2012), затриманням продуктів розпаду мієліну та закисленням середовища. При цьому виявляється закономірне підвищення концентрації кінинів, які викликають парез аретріол, підвищення проникності судин, порушують місцеві ферментативні системи та підвищують чутливість тканин до кисневого голодування (Aman et al., 2016). За словами В. П. Котельникова (Popel’, 2017), «трагедія тканин у ділянці охолодження полягає в тому, що вони не утилізують навіть той кисень, який до них надходить». Саме це пояснює весь спектр морфологічної перебудови, що відбувається у мієлінових нервових волокнах до 30-ї доби експерименту.

Виявлені зміни, що відбуваються у метричному складі мієлінових нервових волокон (підвищення кількості дрібних нервових волокон), можна пояснити не тільки усуненням набряку через 45 діб після початку моделювання експериментальної нейропатії, а й активацією ремієлінізувальних процесів, тоді як зниження числа великих нервових волокон відбувається внаслідок зменшення їх набряку. Подібні результати знаходимо у працях інших авторів (Hellwig, 2002; Cohen et al., 2015; Popel', 2017), які досліджували метричний розподіл мієлінових нервових волокон за нейропатій в інших периферичних нервах.

Поряд із нервовими волокнами через 10 діб після початку експерименту в мімічних м'язах спостерігається розширення артеріол, прекапілярів і капілярів, пов’язане, на думку окремих дослідників (Zheng et al., 2012; Lomako et al., 2016; Plotnikov et al., 2016), iз розвитком паралітичної вазодилатації після холодової травми. За ходом нервових волокон спостерігаються варикозоподібні потовщення, що чергуються з потоншеннями.

Такі зміни нервових волокон, як це доведено Mumtaz and Jensen (2014), Tuhrim (2016), Hamel and Logigian (2017), - peзультат не тільки їх безпосереднього ушкодження холодовим фактором, а й впливу механічного подразнення (компресія розширеними кровоносними судинами та навколишніми тканинами, які перебувають у стані локального набряку, а також внаслідок розтягування та розшарування міжм'язових сполучнотканинних прошарків). Оскільки тварин цієї серії досліду досліджували в ранній термін, в який ще не могло відбутися суттєвих органічних змін внутрішньої структури нервових волокон, виникнення їх локальних потовщень і потоншень у даному випадку можна розглядати як результат дії на нерв винятково змін, що відбуваються в навколишніх м’язах (Popel', 2017). При цьому частина нервових волокон за впливу набряку переміщується в менш стиснені ділянки нерва. Перебудови нервово-м'язових закінчень у цих тварин ще не спостерігається.

Через 15 діб після початку моделювання експериментальної нейропатії у м'язових і нервових елементах мімічних м'язів відбуваються значні структурні зміни, а їх різноманіття, характер і ступінь вираженості окремі автори (Plotnikov et al., 2016) пояснюють неоднаковою стійкістю різних нервово-м'язових елементів до холодової травми. У кінцевих гілках лицевого нерва, які інневрвують мімічні м’язи за впливу локального набряку, розвиваються три процеси: явище подразнення, структурна перебудова за типом деструкції та дегенеративні зміни частини нервових волокон (Smith et al., 2012). Ознаки подразнення нерва, як і в попередній термін досліду, відбуваються в результаті компресії та розтягування, які, за даними Hamel and Logigian (2017), закономірно розвиваються у паралізованих м’язах.
Крім цього, явища локального подразнення викликають також продукти метаболізму, які нагромаджуються у м'язах (Achiron and Miron, 2007; Keith, 2010). За значно вираженої дії цих чинників може відбуватися не тільки переміщення нейроплазми в менше стиснені місця та утворення тут сегментарних потовщень і натікань, не виключається також, що це деякою мірою спричинює дегенерацію термінальних ділянок. Підтвердження цьому - експерименти, які проводив Popel' (2017). За тривалої гіпокінезії та нейропатії він спостерігав однотипні зміни у вигляді дрібнозернистого розпаду терміналей нервових волокон і дегенерацію нервово-м’язових закінчень.

За вимушеної фізичної бездіяльності - гіпотрофія м’язових волокон, поздовжнє розщеплювання м'язових пучків I і II порядку, зміна хімізму мімічних м'язів та їх кровообігу (Boissaud-Cooke et al., 2015; Lemaster et al., 2017), а також сам факт холодової дії стають поштовхом до спраутингу складових елементів нервової системи м'язів.

Необхідність кращого проведення нервових імпульсів на м’яз під час деінерваційної гіпокінезії реалізується різними шляхами. Перш за все, перебудовуються претермінальні ділянки нервових волокон, які, як відомо з праці Ali et al. (2015), стають найлабільнішою частиною аксона. Відбувається набухання претерміналей, що супроводжується погіршенням проведення імпульсу та полегшує функцію центральної нервової системи. Крім того, змінені нервово-м'язові закінчення не здатні реалізувати медіатор, що акумулюється у претермінальній ділянці, чим i пояснюється виникнення у претермінальних ділянках сильновираженних натікань аксоплазми. Це, у свою чергу, також стимулює деструкцію рухових нервових закінчень. Під час мікроскопічного дослідження нервово-м’язових закінчень кругового м’яза рота через 15 діб експерименту встановлено, що у претермінальних ділянках утворюються варикозні розширення мієлінових нервових волокон. Змінюється також площа розгалуження термінальних гілочок рухового аксона (табл.).

Через 30 діб після початку моделювання нейропатії лицевого нерва спостерігається проліферація кінцевих елементів існуючих рухових нервових закінчень, яка здійснюється за двома типами: примітивнішому - телодендрій i досконалому нервово-м'язових закінчень. У першому випадку спостерігається сильне розростання терміналей уздовж м'язових волокон, де вони утворюють досить розгалужені сплетення. Часто в таких випадках на кінцях терміналей зустрічаються колби росту. Проліферація рухових нервових закінчень другого типу полягає у тому, що збільшується кількість термінальних гілочок і ядер шванівських клітин (нейролемоцитів). Іноді в таких нервово-м'язових закінченнях виявляють 15 і більше ядер. Ядра мають різний ступінь забарвлення від ясно-жовтого до темно-коричневого та навіть чорного кольору (якщо не проводилося золочення препарату), що свідчить про їх різну зрілість (Popel', 2017). Отже, нервові елементи, менш імпрегновані, молодші порівняно із сильніше імпрегнованими структурами, що зустрічаються на цьому ж препараті.

Часто ми спостерігали також іннервацію одного м’язового волокна двома різними руховими нервовими волокнами, що дещо рідше зустрічаються в нормі (Hellwig, 2002; Reina et al., 2015).

У низці випадків спостерігали двократний дихотомічний спраутинг нервового волокна у претермінальній ділянці, внаслідок чого нервове волокно іннервує два, три та навіть чотири м'язові волокна. Факт іннервації одним нейроном великої кількості м'язових волокон відомий. Але в цьому випадку бачимо перебудову претермінальної ділянки нервового волокна за денерваційної бездіяльності. Доказ цього - наявність ще не цілком сформованих рухових нервових закінчень і колб росту на кінцях деяких колатеральних гілок. Зустрічалися також випадки, коли на одному м'язовому волокні руйнувалися власні нервово-м'язові закінчення, і до нього направлялася термінальна гілочка, яка проростала за його межі від сусіднього м'язового волокна. Тут вона утворювала нове рухове нервове закінчення. 
Якщо зміни у нервових волокнах тривають 60 діб, то велика кількість м'язових волокон піддається деструкції, а розміри значної частини нервово-м'язових закінчень зменшуються (табл.). Деякі 3 них зменшуються в розмірах, їх ядра сильно імпрегнуються. Часто зустрічається гіперімпрегнація нервовом’язових закінчень, а деякі з них піддаються деструкції, до якої залучається також частина нервових волокон. Щодо стану нейролемоцитів в умовах нейропатії, вони проявляють свою реакцію досить одноманітно. Цитоплазма цих клітин набухає. В ядрах виявляються аргірофільні зерна, які іноді розплавляються, в результаті чого все ядро набуває суцільного темного забарвлення. Лише у випадках важкої хронічної нейропатії відбувається грудочковий розпад ядер окремих нейролемоцитів.

Оцінюючи питому вагу прогресивних і регресивних морфологічних перетворень у м'язах і наявність стійких структурних змін під час експериментальної нейропатії (включаючи випадки важкого хронічного рецидивування), можна відзначити деяку перевагу регресивних явищ. За нашими даними та результатами досліджень інших авторів (Azizzadeh et al., 2014; Fayad and Linthicum, 2014; Popel', 2017), під час тривалого деструктивного процесу в м'язових волокнах ми можемо стверджувати, що за таких умов відбувається не тільки перебудова, а й адаптація до нових умов діяльності всіх нервових і судинних елементів периферичного нерва.

Погіршення умов утилізації кисню та тканинного метаболізму - причина тривалого субкритичного набряку ендоневрія, сповільненого відновлення структури мієлінових нервових волокон та їх кінцевих закінчень - субстрату для можливих рецидивів нейропатії лицевого нерва (Zheng et al., 2012).

\section{Висновки}

За морфометричними параметрами лицевий нерв кроля складається з 2-6 основних пучків із середнім вмістом $9278 \pm$ 341 нервове волокно. Волоконний склад пучків на всіх рівнях схильний до значних індивідуальних коливань. Більшість мієлінових нервових волокон $(54,6 \%)$ належить до групи великих волокон (d > 7,0 мкм) з унімодальним характером розподілу. Кількість капілярів складає в середньому 140,0 0 3,9. У ділянці локального охолодження лицевого нерва відбуваються фазові зміни компонентів внутрішньостовбурового мікроциркуляторного русла та структури мієлінових нервових волокон із порушенням будови компонентів сполучнотканинних оболонок нерва. Виділено три фази динаміки холодової нейропатії: a) реактивно-дистрофічних змін із максимальною вираженістю на 10-ту добу досліду; б) деструктивно-відновних процесів, що починаються з 15-ї доби досліду; в) компенсаторно-адаптаційна із залишковими явищами, яка розвивається після 30-ї доби досліду. Вплив локального переохолодження знаходить певний морфологічний прояв у зміні структури всіх компонентів нейромоторних одиниць мімічних м'язів, які характеризуються якісними та гістометричними змінами. У процесі розвитку експериментальної холодової нейропатії відбувається структурно-пристосувальна перебудова нервово-м’язових закінчень, яка залежить від терміну спостереження та відображає функціонування мімічного м'яза.

\section{References}

Abramowitz, H. B., \& Gertz, S. D. (2007). Guideline for prevention of venous stasis. AORN Journal, 85(3), 607-624.

Abramowitz, H. B., \& Gertz, S. D. (2007). Venous stasis, deep venous thrombosis and airline flight: Can the seat be fixed? May Annals of Vascular Surgery, 21(3), 267-271.

Achiron, A., \& Miron, S. (2007). Myelin associated antibodies: Myelin-associated glycoprotein autoantibodies, myelin basic protein autoantibodies and myelin proteolipid autoantibodies in neurologic diseases. Autoantibodies, 619-626.
Ali, Z. S., Heuer, G. G., \& Zager, E. L. (2015). Nerve compression / entrapment sites of the upper limb. In: Nerves and nerve injuries. Raven Press, New York. pp. 725-753.

Aman, J., Weijers, E. M., Amerongen, G. P. van N., Malik, A. B., \& van Hinsbergh, V. W. M. (2016). Using cultured endothelial cells to study endothelial barrier dysfunction: Challenges and opportunities Amerian Journal of Physiology. Lung Cellular and Molecular Physiology, 311(2), 453-466.

Azizzadeh, B., Kulbersh, J. S., \& O’Connell, B. P. (2014). Facial nerve paralysis examination. In: The facial nerve. Thieme Verlagsgruppe, Stuttgart. pp. 345-367.

Boissaud-Cooke, M., Pidgeon, T. E., \& Tunstall, R. (2015). The microcirculation of peripheral nerves. In: Nerves and nerve injuries. Raven Press, New York. pp. 507-523.

Cohen, J. A., Guardia, C. F., Mowchun, J. J., \& Stommel, E. W. (2015). Demyelinating diseases of the peripheral nerves. In: Nerves and nerve injuries. Raven Press, New York. pp. 895-934.

Craig, W., \& Stone, J. (2015). Information and phylogenetic systematic analysis. Information, 6(4), 811-832.

Fayad, J. N., \& Linthicum Jr., F. H. (2014). Histopathology of facial nerve disorders. In: The facial nerve. Thieme Verlagsgruppe, Stuttgart. pp. 22-25.

Feuerstein, T. J. (2008). Presynaptic receptors for dopamine, histamine, and serotonin. Handbook of Experimental Pharmacology, 289-338.

Gitik, M., Liraz-Zaltsman, S., Oldenborg, P. A., Reichert, F., \& Rotshenker, S. (2011). Myelin down-regulates myelin phagocytosis by microglia and macrophages through interactions between $\mathrm{CD}_{47}$ on myelin and SIRP $\alpha$ (signal regulatory protein- $\alpha$ ) on phagocytes. Journal of Neuroinflammation, 8(24), 344-352.

Hamel, J., \& Logigian, E. L. (2017). Acute nutritional axonal neuropathy. Muscle and Nerve, 122(7), 34-39.

Hellwig, B. (2002). Cyto- and myeloarchitectonics. Conceptual advances in brain research. In: Nerves and nerve injuries. Raven Press, New York. pp. 15-28.

Keith, J. M. (2007). Dual serotonin transporter / histamine $\mathrm{H}_{3}$ ligands: Optimization of the $\mathrm{H}_{3}$ pharmacophore. ChemInform, 38(22).

Keith, J. M. (2010). Serotonin (5-HT2A) receptor; histamine $\mathrm{H}_{1}$ receptor (HRH1). Science-Business eXchange, 3(43).

Lemaster, M., Pidgeon, T. E., \& Tunstall, R. (2015). The microcirculation of peripheral nerves. In: Nerves and nerve injuries. Raven Press, New York. pp. 507-523.

Lomako, V., Shylo, A., Babijchuk, G., Samokhina, L., \& Malaya, L. T. (2016). Craniocerebral hypothermia stimulates reactions of limited proteolysis in rat tissues. Problems of Cryobiology and Cryomedicine, 26(3), 238-248.

Mumtaz, S., \& Jensen, M. B. (2014). Facial neuropathy with imaging enhancement of the facial nerve: A case report. Future Neurology, 9(6), 571-576.

Nanba, R., Fujita, N., \& Nagata, S. (2010). Structure and expression of myelin basic protein gene products in Xenopus laevis. Gene, 459, 32-38.

Nawaz, S., Schweitzer, J., Jahn, O., \& Wemer, H. B. (2013). Molecular evolution of myelin basic protein, an abundant structural myelin component. Glia, 61(8), 1364-1377.

Plotnikov, G. P., Galimzyanov, D. M., Shukevich, D. L., Matveeva, V. G., \& Grigoriev, E. V. (2016). Therapeutic hypothermia as a method for prevention of multiple organ failure in critically ill patient. Fundamental and Clinical Medicine, 1(3), 14-23.

Popel', S. L. (2017). Structural changes in skeletal muscles in hypokinesia and physical loading in the posthypokinetic period of rats organism restoration. Regulatory Mechanisms in Biosystems, 8(2), 58-65.

Reina, M. A., Sala-Blanch, X., Arriazu, R., \& Machés, F. (2015). Microscopic morphology and ultrastructure of human peripheral nerves. In: Nerves and nerve injuries. Raven Press, New York. pp. 91-106.

Smith, P. M., Gonçalves, R., \& McConnell, J. F. (2012). Sensitivity and specificity of MRI for detecting facial nerve abnormalities in dogs with facial neuropathy. Veterinary Record, 171(14), 349-349.

Tracz, E., Zamojska, E., Modrzejewski, A., Zaborski, D., \& Grzesiak, W. (2015). Quality of life in patients with venous stasis ulcers and others with advanced venous insufficiency. Holistic Nursing Practice, 29(2), 96-102.

Tuhrim, S. (2016). Vascular diseases. In: Mount Sinai Expert Guides: Neurology. John Wiley \& Sons, Ltd., 220-240.

Wagner, O. F., Nowotny, P., Vierhapper, H., \& Waldhäusl, W. (2008). Plasma concentrations of endothelin in man: Arterio-venous differences and release during venous stasis. Clinical Investigation, 20(5), 502-505.

Watanabe, T., \& Suzuki, M. (2016). Equilibrium test findings in patients with Bell's palsy. Auris Nasus Larynx, 33(2), 143-147.

Zheng, Y., Chen, J., Craven, M., Choi, N. W., Totorica, S., Diaz-Santana, A., Kermani, P., Hempstead, B., Fischbach-Teschl, C., López, J. A., \& Stroock, A. D. (2012). In vitro microvasculature network model. Science-Business eXchange, 5(25), 111-120. 